DOI: $10.2478 / \mathrm{v} 10025-010-0006-9$

JOURNAL OF WATER

AND LAND DEVELOPMENT

J. Water Land Dev. No. 13b, 2009: 69-86

\title{
The hydrological properties of waterlogged and drained forests in Latvia
}

\author{
Peteris ZALITIS, Aigars INDRIKSONS
}

Latvian State Forestry Research Institute "Silava”, Rigas iela 111, Salaspils, LV-2169, Lativia, e-mail: peteris.zalitis@silava.lv, aigars.indriksons@silava.lv

\begin{abstract}
Almost half (47\%) of Latvian forest areas (3611 thousand ha) are considered degraded or partly improved by the hydro-technical drainage. The degradation is caused by very poor soil aeration due to waterlogged conditions. The location of waterlogged forests in Latvia is neither uniform nor occasional. Comparison of the abundance of waterlogged forests and the amount of atmospheric precipitation showed that the waterlogged forests are mainly located in areas with least precipitation. This hydrological phenomenon is connected with water discharge in drainage ditches: even during the dry summers of the years 1963, 1964, 1975, 1976 and 2002 in the drained forests with deep peat soils water flowed continuously in $1 \mathrm{~m}$ deep ditches and the discharge exceeded the amount of precipitation. Using the data from 182 sample plots in drained forests with the peat layer depth of $4.2 \mathrm{~m}$, it was found, that coniferous forests are most productive in areas where the peat layer is most dense. One of the possible explanations for this phenomenon is that the most intensive paludification and formation of most dense peat layer are characteristic for the areas with intensive water discharge from confined aquifers. This discharge provides necessary mineral nutrients for the forest soil regardless of the peat layer thickness. The forest productivity may increase several times due to the enhancement of water movement in soil and to improved soil aeration by hydro-technical drainage. Also the flow regime of rivers connected with the drained areas changes considerably, mitigating extremely high and low flow events.
\end{abstract}

Key words: forest paludification, nutrients, water discharge, waterlogged forests

\section{INTRODUCTION}

Latvia is a place rich in water - several decades mean annual water resources of the state reach $15.4 \mathrm{~km}^{3}$. If we add also the throughput waters, we obtain 34.7 $\mathrm{km}^{3}$, which is more than 13 thous. $\mathrm{m}^{3}$ per capita.

Especially favourable water conditions (runoff to rivers exceeds $9 \mathrm{dm}^{3} \cdot \mathrm{s}^{-1} \cdot \mathrm{km}^{-2}$ ) prevail in one sixth $(16 \%)$ of the territory which is mainly occupied by uplands, but an equally large area is occupied by lands poor in water (water flow lower than 6 
$\mathrm{dm}^{3} \cdot \mathrm{s}^{-1} \cdot \mathrm{km}^{-2}$ ) which are usually located in lowlands. Approximately two thirds (67\%) of the state territory can be considered as moderately fed with water.

Wet periods are constantly followed by the dry ones. When analyzing water flow in Daugava River in a 150 years long period (1812-1964), PASTORS (1972) separated 13 periods when rainy weather was replaced by dry one. Dry periods lasted 13 years on average, wet periods - 10 years but the duration of particular periods varied from 6 to 21 years. Reasons of the fluctuations were not determined; a possible connection with the 11-years long solar cycle was not confirmed.

In wet summers $85 \%$ of the territory is richly supplied with water resources while in dry summers a similarly large area $(80 \%)$ may suffer from the lack of water. Surprisingly, in several regions of Latvia (Aizkraukle, Limbazi, Riga, Talsi) threatened by water deficit vast areas of wet and paludified forests can be found.

The process of paludification in Latvia commenced already in the sub-arctic period almost simultaneously with the end of the glacial era and during the past 9 thous. years bogs have formed with the thickness of peat layer reaching $12 \mathrm{~m}$.

At present almost half (47\%) of the total area of Latvian forests can be considered degraded or partially "remediated" with hydro-technical melioration. This degradation is caused by low soil aeration under conditions of excessive moisture.

The distribution of waterlogged forests in the territory of Latvia is neither regular nor random. There are regions where the waterlogged forests make up 75$-95 \%$ of the total area of forests, but elsewhere - only $5-10 \%$. It is reasonable to expect that there should be some special factors which either cause or prevent forest paludification.

Comparing the occurrence of waterlogged forests and the amount of atmospheric precipitation, we suggest that forest paludification cannot be explained by climate changes. For example, dense waterlogged forests cover large areas in Riga - Jelgava plain but the amount of atmospheric precipitation there is the lowest in Latvia. There are also other surprising facts.

A widespread belief in both the former USSR and in several countries of Western Europe is that growing highly productive forests is not possible on deep peat soils. Such opinion was formed based on many field observations. It has also a theoretical background - forest ecosystem is not able to function properly when mineral nutrients are deficient. In peat soil roots of trees do not reach deeper than $40 \mathrm{~cm}$ and there is a large, often several meters deep, break between soil and the basic mineral layer. Nevertheless, highly productive forests can also be found on deep peat soil in Latvia. How is it possible? Where from the trees obtain the essential nutrients?

Another peculiarity worth mentioning is associated with water flow in drainage ditches. In dry summers $(1963,1964,1975,1976,2002)$ water was continuously flowing in approximately one meter deep ditches in drained forests growing on deep peat soils, while at the same time many natural streams and rivers 3-4 m deep had gone absolutely dry. It is clear that a lot more water flows in the shallow 
forest ditches than it would fall down from the atmosphere. An unavoidable question is - where does the water necessary for forest growth come from?

\section{MATERIAL AND METHODS}

The data for this study were collected during the long-term (since 1963) hydrological observations in the Vesetnieki Station of Permanent Ecological Research in the area of drained pine (Pinus sylvestris L.) forests of the Forestry Research Station "Kalsnava" situated in the Central part of Latvia. The following elements of water balance were measured in five water confluence basins of the Vesetnieki Station:

a) precipitation in an open area with $0.2 \mathrm{~mm}$ precision (Tretiakov precipitation gauge), measured daily;

b) net precipitation falling through the forest canopy, recorded with $0.2 \mathrm{~mm}$ precision once every 10 days over the growing season (May 1 to October 31) from 180 rain collectors along 10 transects in different forest stands;

c) density and thickness (with $1 \mathrm{~cm}$ precision) of the snow layer in 10 different forest stands, measured once every 10 days, and during the snowmelt - once every 3 days;

d) water level in the Veseta River with $1 \mathrm{~cm}$ precision - daily;

e) the groundwater level in 150 shallow $(2 \mathrm{~m})$ observation wells with $1 \mathrm{~cm}$ precision, read once every 10 days;

f) piezometric water level in 33 deep $(5-31 \mathrm{~m})$ wells, including 17 wells reaching Upper Devonian horizons of dolomites, with $1 \mathrm{~cm}$ precision read once every 10 days;

g) ditch runoff in $\mathrm{m}^{3}$ with the runoff recording device (Valday type) changed once a week (in 5 hydrometric posts).

Moreover, measurements of nutrient balance were carried out twice a month since 1997. The quality of precipitation water falling on the forest ecosystem was analysed using water from 24 precipitation collectors. The collectors had a surface area of $106 \mathrm{~cm}^{2}$ and were deployed as follows: 5 in an open area, including 1 at the station's centre, 4 around the perimeter of the experimental area at a distance of 1.0 $\mathrm{km}$ from the station's centre; 19 in the forest stands of pine (5), spruce (6) and birch (4), and in a young coniferous tree stand (4). To calculate the output of nutrients in streamflow, one-litre samples were taken at each of 5 hydrometric posts. Three of these samples represent ditch runoff water from the catchments with a deep peat layer, while the remaining 2 hydrometric stations monitor catchments with hydromorphic mineral soils. For each water sample the concentrations of $\mathrm{N}-\mathrm{NH}_{4}, \mathrm{~N}-\mathrm{NO}_{3}, \mathrm{P}-\mathrm{PO}_{4}, \mathrm{~K}^{+}, \mathrm{Ca}^{2+}, \mathrm{Mg}^{2+}$ and $\mathrm{pH}$ were determined in the Forest Soil Laboratory of the Latvian Forestry Research Institute "Silava". In total 17,600 water sample were analysed. 
Environmental data from a number of Latvian forest management units were also used. In order to clarify whether discharge intensity of the confined aquifer water influence productivity and typological structure of forests on drained deep peat soils, the conditional intensity $(R)$ of this water discharge was calculated for 153 forest plots of Western and Eastern Latvia. The line between Riga and Bauska cities was used as the borderline. In the whole area the thickness of quaternary sediments $(L)$, elevation of soil surface $(H)$ and piezometric level of confined aquifer water $(h)$ were assessed. The intensity of confined aquifer water discharge was calculated as:

$$
R=(h-H) / L
$$

The data from 182 evaluation plots in forests with peat soils from different regions of Latvia were collected to analyse the relationship between pine and spruce tree stand productivity and the thickness of peat layer.

The groundwater regime and the forest stand productivity were obtained by comparing the mean groundwater depths calculated in different places of drained forests during vegetation period. Groundwater levels were compared in pine forests of the I-II site index, III site index and of the IV-V site index.

To compare the typological structure of waterlogged forests and the intensity of confined aquifer water discharge, archive materials of the State Melioration Institute and the Marine Institute of Geology were analysed. 298 sites of waterlogged forest and mires suitable for drainage, where at least one type of forest site or mire exceeded 25 ha, were assessed.

\section{RESULTS AND DISCUSSION}

The reason for paludification of forests is still seen in the amount of precipitation exceeding by $1.5-2.0$ times evaporation in Latvia. It is not known who was the first to express such an idea, but it is being used for several generations in order to explain the causes of paludification and to argue in favour of hydro-technical melioration in Latvia. If it is so, then the occurrence of waterlogged forests should positively correlate with the amount of precipitation, but negatively - with the indicators of evaporation.

Correlation between the evaporated amount of precipitation and the contribution of waterlogged forests in forest management districts is diametrically opposed to the expected: it is significantly positive: $r=+0.36$ with $r_{0.05}=0.12$, which means that there are more waterlogged forests in areas where more precipitation evaporates (ZALITIS, 1983). Correlation, however, is not causation. The opposite explanation is more correct: waterlogged forests are the reason of higher evaporation. 
The long-term average precipitation in the territory of Latvia varies between 600 and $970 \mathrm{~mm}$; in summer (01.05.-31.10.) it ranges from 365 to $560 \mathrm{~mm}$ (ANONYMOUS, 1968). The difference in precipitation between dry and wet summers in the same place is also the same. For example, in Vesetnieki station there were $169 \mathrm{~mm}$ of precipitation in summer 1975 but $692 \mathrm{~mm}$ in summer 1980 - so the difference was $523 \mathrm{~mm}$ (ZALITIS, 1983).

All these data unequivocally show that it would be incorrect to assume the relationship or difference between precipitation and evaporation as the main precondition of paludification of territories. Furthermore, evaporation from terrestrial ecosystems is not just a physical process - it is one of self-reservation instruments of ecosystems. The amount of water which evaporates from terrestrial ecosystems is not a constant value which characterizes a territory and could not be used as a background indicator.

Water discharge from confined aquifer is the most significant component of waterlogged forest water balance. In waterlogged forests the piezometric levels of water in confined aquifer in many areas not only reach soil surface but exceed it by $30 \mathrm{~m}$. Under such pressure soil water is continuously supplemented by water from confined aquifer and this input can be evaluated as the main reason of forests paludification. It can also be verified by the results of correlation analyses: the percentage of waterlogged forests in forest districts quite closely correlates $\left(r=-0.59\right.$ with $\left.r_{0.05}=0.12\right)$ with piezometric level of confined aquifer water. Hence, more waterlogged forests can be found in areas where the piezometric level is closer to soil surface or is even higher than that.

Results of the analyses of 298 sites selected by the State Melioration Institute and the Marine Institute of Geology convincingly confirmed the decisive role of confined aquifer water in the paludification process: $86 \%$ of forests on peat soils and $60 \%$ of forests on hydro-morph mineral soils are located in places where the piezometric level of confined aquifer water reaches and elevates above soil surface (Fig. 1).

Water discharge from confined aquifers in both waterlogged and drained forests on peat soils varies in quite a broad range across the country depending on the difference between piezometric levels of soil groundwater and confined aquifer water, the length of filtration path and soil density and on the depth of soil groundwater level. The discharge is usually high - approximately $100 \mathrm{~mm}$ per year which together with rain and snow precipitation supplement reserves of soil moisture with waters richer in nutrients.

The problem of the influence of hydro-technical drainage on the intensity of water discharge from confined aquifer is often discussed. The intensity of discharge changes in relation to the changes in pressure of confined aquifer water (Darcy's law). When soil groundwater level decreases (as a result of drainage) at constant piezometric level of confined aquifer water the pressure raises and the discharge of water from confined aquifer increases. The results of our measurements 


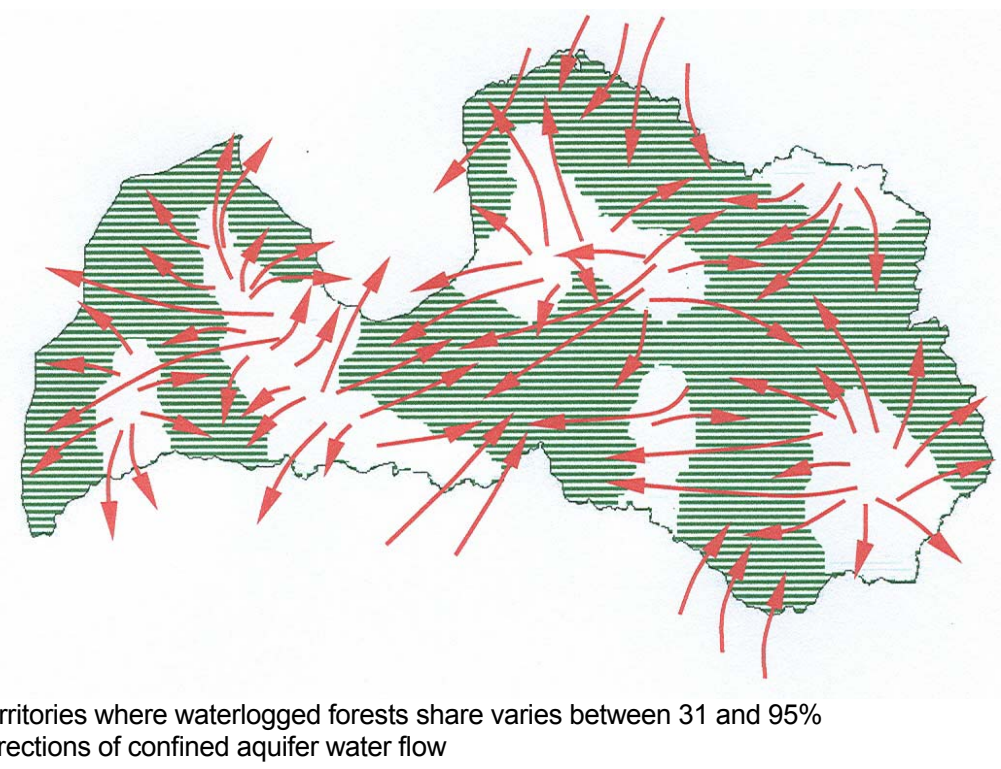

Fig. 1. Waterlogged forest distribution in relation to confined aquifer water feeding and discharge regions; $r_{\mathrm{W}, \mathrm{P}}=-0.24, r_{0.05}=0.11, P$ - precipitation, $W$ - contribution of waterlogged forests

show that in Jaunkalsnava, in drained forests on deep peat soils of the area of Vesetnieki Station of Permanent Ecological Research the decline of forest soil groundwater level by $25 \mathrm{~cm}$ increased confined aquifer water inflow by $0.1 \mathrm{~mm}$ per day or by $35 \mathrm{~mm}$ annually. This example illustrates both the fact that forest drainage, promoting discharge of confined aquifer water in drained forest lands, supplements river and spring flows mainly in dry summers, and the fact that there is a higher delivery of nutrients to soils of drained forests. High productivity of these forests does not decrease but continuously increases also in prolonged periods of time (ZALITIS and INDRIKSONS, 2003). It is a unique situation which is not found either in Finland or in other Scandinavian countries with a different water balance in waterlogged forests and a completely different ecologic role of these waters.

When planning hydro-melioration and other measures of water management, straightening and deepening of natural streams and rivers should specifically be avoided. Natural water flows often drain Upper Devonian horizons that are filled with confined aquifer water. As the result of river deepening the protective layer of water in the bottom of the bed is destroyed, pressure of confined aquifer water decreases in large areas, streams dry up, productivity of peat soils can also deteriorate and the usual water management can change irreversibly.

Upon comparison of the average discharge intensities $(R)$ in Western and Eastern regions of Latvia (Tab. 1), two regularities were outlined. 
Table 1. The intensity of water discharge from confined aquifer $(R)$ in different types of drained forest sites on deep peat soils ( $n$ - number of sites)

\begin{tabular}{l|c|c|c|c}
\hline \multirow{2}{*}{\multicolumn{1}{c}{ Forest site type }} & \multicolumn{2}{c|}{ Western Latvia } & \multicolumn{2}{c}{ Eastern Latvia } \\
\cline { 2 - 5 } & $n$ & $R$ & $n$ & $R$ \\
\hline Callunosa turf.mel., Kv & 19 & 0.43 & 24 & 0.32 \\
Vacciniosa turf. mel., Km & 10 & 0.68 & 21 & 0.44 \\
Myrtillosa turf. mel., Ks & 9 & 1.41 & 25 & 0.62 \\
Oxalidosa turf. mel., Kp & 13 & 1.58 & 32 & 1.05 \\
\hline
\end{tabular}

First - in the most productive type of forest sites $(\mathrm{Kp})$ confined aquifer water is discharged with approximately three times higher intensity than in the poor forest site type $(\mathrm{Kv})$. Second - within a given forest type the discharge is significantly larger in the western than in the eastern zone. This is most probably associated with the structure of quaternary sediments: waterlogged forests in the western zone grow mainly on sandy soils which were outwashed many times in the glacial age. Such sands are widespread in coastal lowland, in the Venta River - Usma Lake system and in Riga sandy plain. The substratum rich in nutrients in Eastern Latvia undeniably increases the role of confined aquifer water in nutrient supply to forest stands.

Hence, there is one, so far less studied common denominator of the surprising facts described above - the hydro-geological situation. The water that flows in ditches of drained forests on deep peat soils is not only precipitation throughfall but also aquifer water confined under Quaternary sediments of the Upper Devonian dolomite. This water is rich in mineral nutrients, especially in calcium and magnesium which exert positive influence on many agrochemical indicators of peat soils. Hence, we may expect that in forests on deep peat soils tree roots do not need to search for nutrients in the bottom of peat layer - the confined aquifer water push these substances to the roots through a thick layer of peat.

Mineral nutrients form one of the five irreplaceable elements which regulate persistence and productivity of forest ecosystems. Productivity of waterlogged forests depends to a great extent on the "import" of mineral nutrients because tree roots do not reach deeper than $40 \mathrm{~cm}$ in the upper peat layer but the thickness of peat layer quite often reaches five meters. Mineral nutrients delivered in dry and wet atmospheric precipitation penetrate peat soil in minute amounts and in the raised bogs the amount of nutrients declines exponentially with the distance from mineral bottom. Fifty $\mathrm{cm}$ away from the mineral bottom there are enough nutrients in peat to grow pine stands of the I-II site index, but $200 \mathrm{~cm}$ away the potential possibilities allow for growing only pine stands of the IV-V site index. This is valid irrespective of how intensely the area is dried. Based on data collected in 182 taxation plots in forests with peat soils, the relationships between pine and spruce stand productivity and the thickness of peat layer were analysed. Within the selec- 
tion the thickness of peat layer varied from 0.3 to $4.2 \mathrm{~m}$, and site indexes which characterize forest stand - from $\mathrm{I}^{\mathrm{a}}$ (in calculations equalled to zero site index) to III.5. Sample plots in the raised bogs were not included in selection.

In pine forests the relationship is expressed by a regression equation:

$$
B=2.63-0.22 K
$$

where

$B$ - current site index of the forest stand;

$K-$ thickness of peat layer, $\mathrm{m}$.

In spruce forests this relationship is expressed as:

$$
B=0.68-0.08 K
$$

Although the equations seem to indicate that the thicker is peat layer the higher is forest productivity, the relationship is statistically insignificant $-r_{\text {fact }}=$ $-0.06, r_{0.05}=0.21$. But the results of analyses still verify a unique regularity which is unusual elsewhere - forest productivity does not depend on the thickness of peat.

Thus, the sites paludify more rapidly and the peat layer becomes thicker in places of more intense water discharge from confined aquifers that are rich in mineral substances. This provides mineral substances necessary for growing of trees independent of the thickness of peat layer.

Physically, the intensity of water discharge from confined aquifer is directly proportional to the difference $(\Delta h=h-H)$ between the piezometric level of confined aquifer water $h$ and the level of soil groundwater $H$ and to the coefficient of water conductivity, and inversely proportional to the length of the filtration path $l$ (ZALITIS, 1983). After combining all 293 measurements in a forest with deep peat layer with $\Delta h$ fluctuating between $-169 \mathrm{~cm}$ and $+284 \mathrm{~cm}$, a significant relationship was found between $\Delta h$ and ionic concentration (Figs 2, 3). The coefficient of correlation between $\Delta h(\mathrm{~cm})$ and $\mathrm{Ca}^{2+}$ concentration $\left(\mathrm{mg} \cdot \mathrm{dm}^{-3}\right)$ was $r=+0.66$; that between $\Delta h(\mathrm{~cm})$ and $\mathrm{Mg}^{2+}$ concentration $\left(\mathrm{mg} \cdot \mathrm{dm}^{-3}\right)-r=+0.52$, at $r_{0.05}=0.11$.

The relationship between $\Delta h$ and ion concentration is described by regression equations:

$$
\begin{gathered}
\mathrm{Ca}^{2+}=0.1121 \Delta h+21.9 \\
\mathrm{Mg}^{2+}=0.0343 \Delta h+7.5
\end{gathered}
$$

From 242 measurements of $\mathrm{Ca}^{2+}$ and $\mathrm{Mg}^{2+}$ concentrations in soil groundwater of the forests on drained (hydro-morph) mineral soils (the thickness of peat layer 


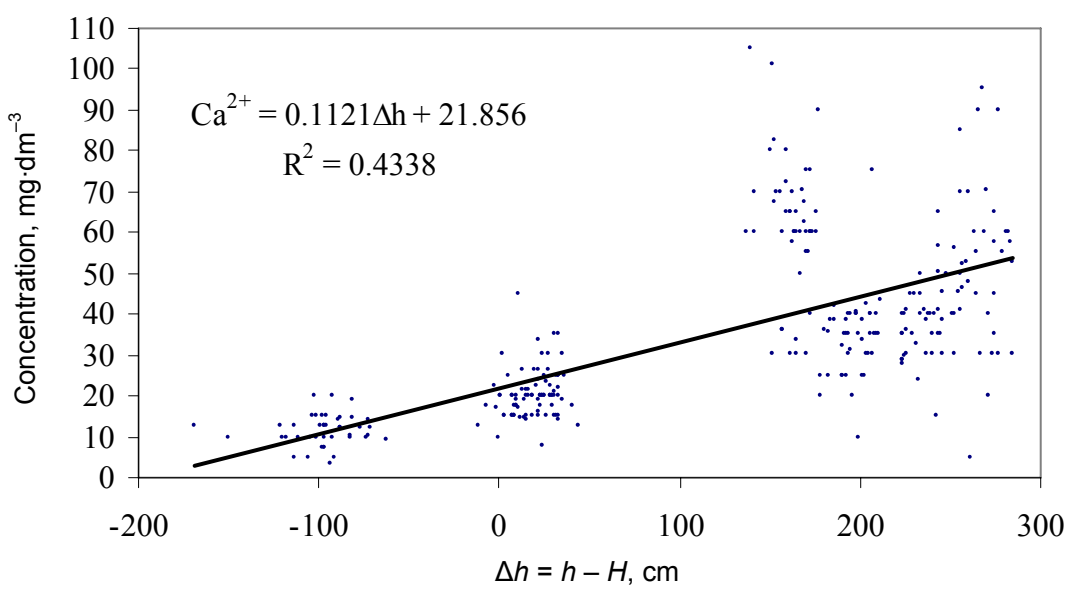

Fig. 2. Calcium $\left(\mathrm{Ca}^{2+}\right)$ concentration in soilwater and groundwater as a function of $\Delta h=h-H$ in forests with deep peat layer

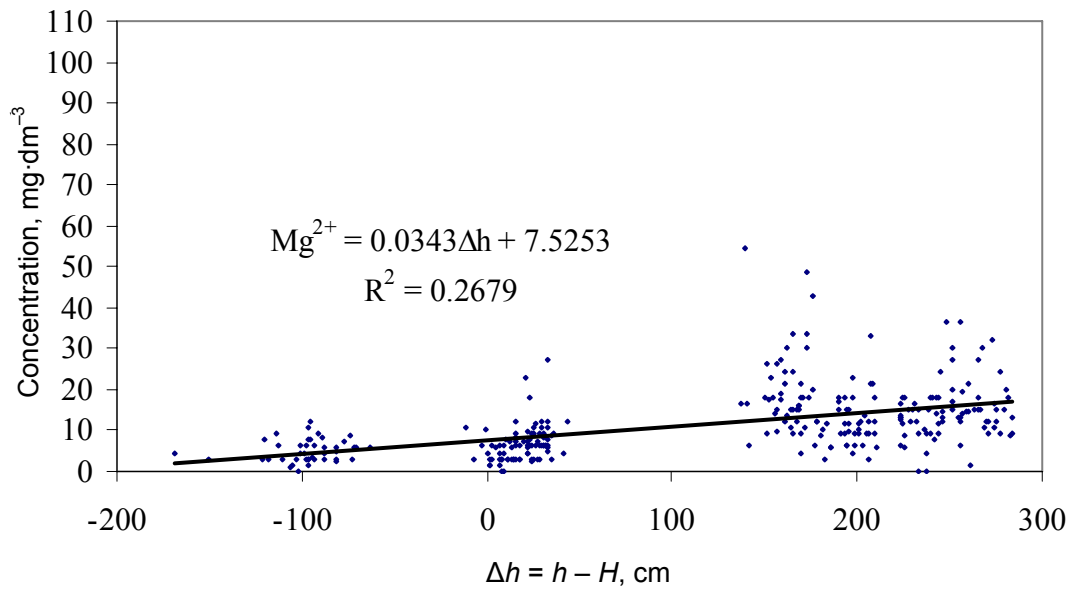

Fig. 3. Magnesium $\left(\mathrm{Mg}^{2+}\right)$ concentration in soilwater and groundwater as a function of $\Delta h=h-H$ in forests with deep peat layer

does not exceed $20 \mathrm{~cm})$, the following mean $\left({ }_{-} S D\right)$ data were obtained: $\mathrm{Ca}^{2+}-26.8$ $( \pm 2.1) \mathrm{mg} \cdot \mathrm{dm}^{-3}$ and $\mathrm{Mg}^{2+}-9.8( \pm 0.6) \mathrm{mg} \cdot \mathrm{dm}^{-3}$. After inserting these numbers into the above described regression equations we obtain the following $\Delta h$ values: $\Delta h=$ $44 \mathrm{~cm}$ for calcium concentration and $\Delta h=67 \mathrm{~cm}$ for magnesium concentration. From these results we can conclude that in forests with thick peat layer the difference of $\Delta h \approx 0.5 \mathrm{~m}$ between water level of confined aquifer and soil groundwater level can ensure the same concentration of calcium and magnesium ions in soil groundwater as that found in hydro-morph mineral soils. If $\Delta h>0.5 \mathrm{~m}$, then peat 
soils are better supplied with calcium and magnesium than in hydro-morph mineral soils where $\Delta h$ has negative sign and forest gains the nutrients directly from mineral soil horizons.

This also explains the fact that in drained peat soils with a relatively thin peat layer $(0.5-1.0 \mathrm{~m})$ surrounded by dry lands, where nutrients flow from the nearby mineral soils, productivity of forests is often lower than the productivity of forests located far away from dry slopes in places with thick peat layer $(2-5 \mathrm{~m})$. In the latter the flow of mineral substances is ensured by an increased discharge of confined aquifer waters.

The first large scale draining works were commenced in Riga City forests when the head of forestry in the years 1847-1882 was Heinrich Frice. He was surprised by intense paludification processes which resulted, as he remarked, in the fact that during one generation highly productive forests had become bog woodlands. Therefore, H. Frice on his own accord organized ditch digging in forests and already in 1851 an $11 \mathrm{~km}$ long channel was dug in the former Cena district till Lake Babīte.

Eugen Ostwald is considered the first organizer of scientifically based forest melioration who after the death of $\mathrm{H}$. Frice was the manager of Riga forests from 1883 till 1906 and from 1878 till 1900 was a docent of forest sciences in the Riga Polytechnical Institute. A special forest melioration fund was organized upon his proposal where a part of forest income was deposited. E. Ostwald was the first author in the world of a study on the influence of draining on tree growing (OSTWALD, 1878). He also believed that draining deep raised bogs was not rational and recommended only their limitation by ditches in order to stop bog expansion.

Planned forest draining expanded since 1929. It was promoted by the very wet summer of 1928. All the lower places were flooded that year, forests started paludification, trees were withering and forest pests widespread.

In the next decade, approximately 15 thous. ha of forests were drained. The Forest Melioration Station of the Forest Department every year studied and designed draining systems for 30-40 thous. ha. Many of the forests that were drained in those years were useful as a basis for general study on the effect of draining on forestry management in the 1950's and 1960's.

During these works a high economic usefulness of forest draining under climatic conditions of Latvia were convincingly proven. In all objects the highest forest productivity was found near ditches, therefore the authors formulated a well reasoned conclusion that over-draining of forests in Latvia was not possible.

The effect of hydro-technical drainage on forest management is very convincing - immediately after digging the ditches the width of tree growth rings increased by many times, even by ten times. The reasons for such improvement remained unknown for many years. It was speculated that the growing season of trees prolonged after lowering of groundwater level in drained forest: in spring trees started to grow earlier and in autumn they were growing longer than in the waterlogged 
forests. Following the development of current increments in growing season indicates that the height increment of coniferous trees and the stem diameter increment commenced simultaneously in drained forests and in forests that were not drained. A slightly (approximately one week) longer growth in autumn in the drained forests turned out to have insignificant influence on the annual tree increments. After drainage the growth rate increased rapidly which resulted also in the additional increment.

In the pre-war years $(1938)$ an average standing crop in Latvian forests $(\approx 2$ million ha) was low - about $100 \mathrm{~m}^{3} \mathrm{ha}^{-1}$. Upon commencement of intense draining works the total productivity of forests (not only the drained forests) rapidly increased and till 1995 it doubled (Fig. 4).

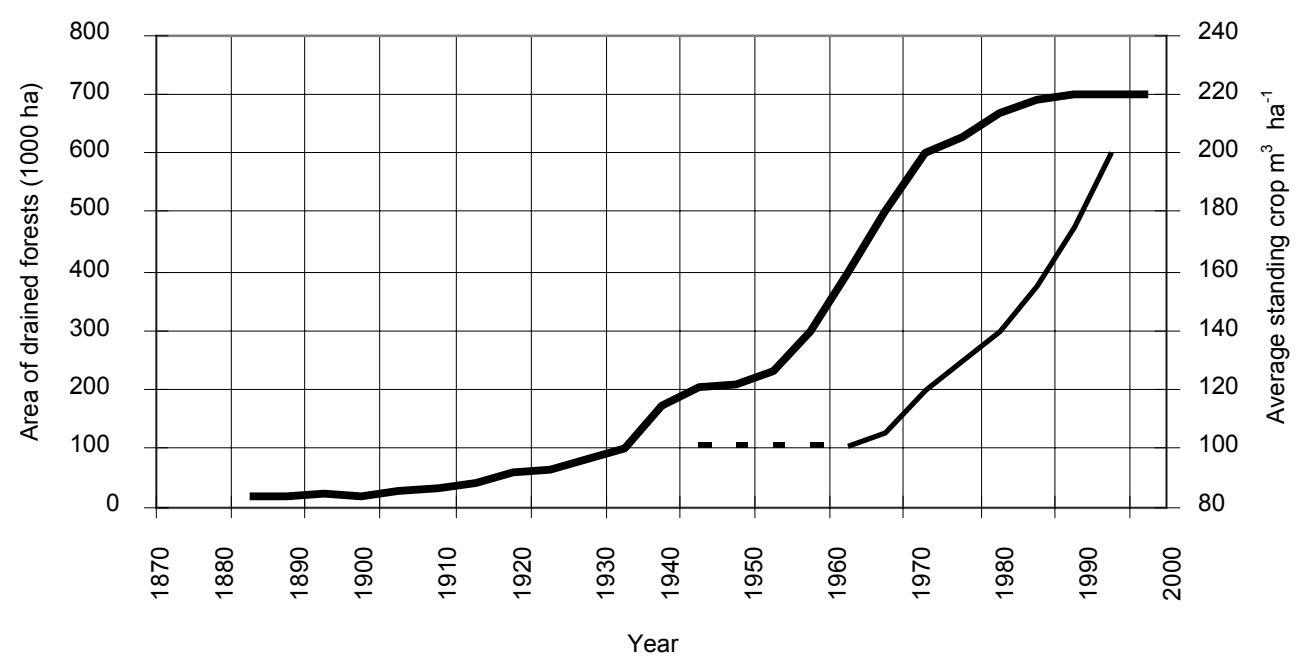

Fig. 4. The drainage of waterlogged forests and forest productivity

Hydro-technical melioration (improvement) of forests also known as "forest drainage" is usually characterized as the lowering of groundwater level. However, results of many studies show that the economic effect of forest melioration reaches much farther from the ditch than mere drainage.

A general perception of the groundwater regime and resulting wood productivity is created when comparing the average groundwater depths calculated in different places in drained forests during vegetation period. Groundwater level in pine forests of the I-II site index is $45-80 \mathrm{~cm}$, of the III site index $-25-80 \mathrm{~cm}$, of the IV-V site index $-25-100 \mathrm{~cm}$. These data illustrate the situation when increased productivity cannot be obtained by simple decrease of soil groundwater level.

Fluctuations of average level of groundwater in the inter-ditch area (the distance between ditches is $270 \mathrm{~m}$ ) in Vacciniosa turf. mel. forest site are characterized by two peaks and two declines (Fig. 5). $15 \mathrm{~m}$ away from the ditch there is 


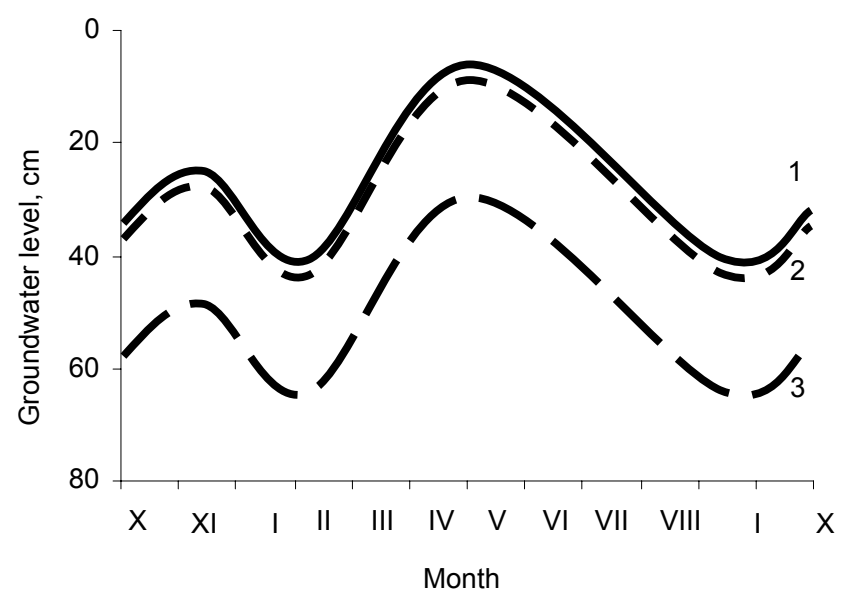

Fig. 5. Groundwater level fluctuation curves in a pine stand (Vacciniosa turf. mel. forest site type); distance from the ditch: $1-135 \mathrm{~m} ; 2-75 \mathrm{~m} ; 3-15 \mathrm{~m}$

a pine forest of the II site index; $75 \mathrm{~m}$ farther - the III site index, but $135 \mathrm{~m}$ farther - a pine forest of the V site index. Groundwater level is most shallow in the end of April and in the beginning of May and gradually lowers till September. In October and November the level slightly rises which is followed by the second lowering stage and in the beginning of March, before snow melting, the water level is situated deepest.

Mean annual water level is: $15 \mathrm{~m}$ from the ditch $-53 \mathrm{~cm}, 75 \mathrm{~m}-34 \mathrm{~cm}$ and $135 \mathrm{~m}-31 \mathrm{~cm}$. Thus, along a $60 \mathrm{~m}$ section the water level lowers only by $3 \mathrm{~cm}$ but forest productivity increases by two site index classes.

Water discharge in the ditches changes similarly to fluctuations of groundwater level. In spring (April, May) $22-45 \%$ of the annual discharge flows through the ditches. The spring maximum discharge is of high importance, summer is the period of minimum discharge intensity. These indicators characterize the influence of hydro-technical drainage on the water regime of natural outflows.

Results of our studies show that discharge from forests with hydro-morph mineral soils is more intense than from forests with peat soils (Figs. 6, 7). Irrespective of soil structure the maximum discharge from drained forests is lower than the discharge from natural outflows. Noteworthy, maximum discharge through ditches occurs some weeks later than that measured in natural outflows. In forests with peat soils the discharge flows uninterruptedly all year round while in forests with hydro-morph mineral soils the discharge temporarily interrupts in dry summers.

Annual nutrient balance in study area showed that the input of $\mathrm{N}_{-} \mathrm{NH}_{4}$, $\mathrm{N}-\mathrm{NO}_{3}, \mathrm{P}_{-} \mathrm{PO}_{4}$ and $\mathrm{K}^{+}$to forest ecosystem in precipitation exceeds the outflow of the same elements by ditch runoff (Tab. 2). The outflow of $\mathrm{Ca}^{2+}$ and $\mathrm{Mg}^{2+}$ in ditch runoff is several times higher than the input of respective elements with precipitation. During the last decade most of forest ecosystems have been recognized as 


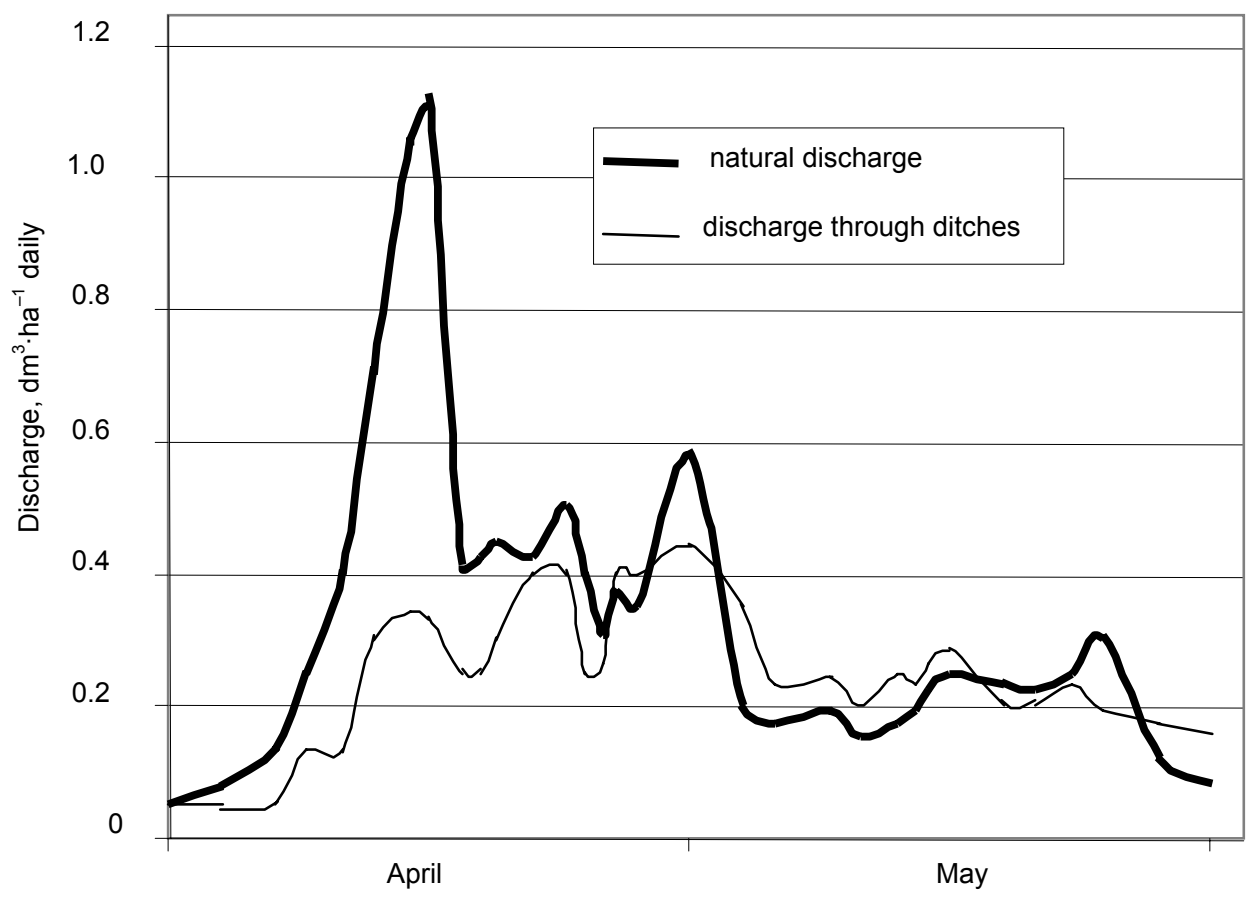

Fig. 6. The regime of water discharge through drainage ditches in 2004 from forests with peat soils compared to the discharge in a natural outflow - the Veseta River

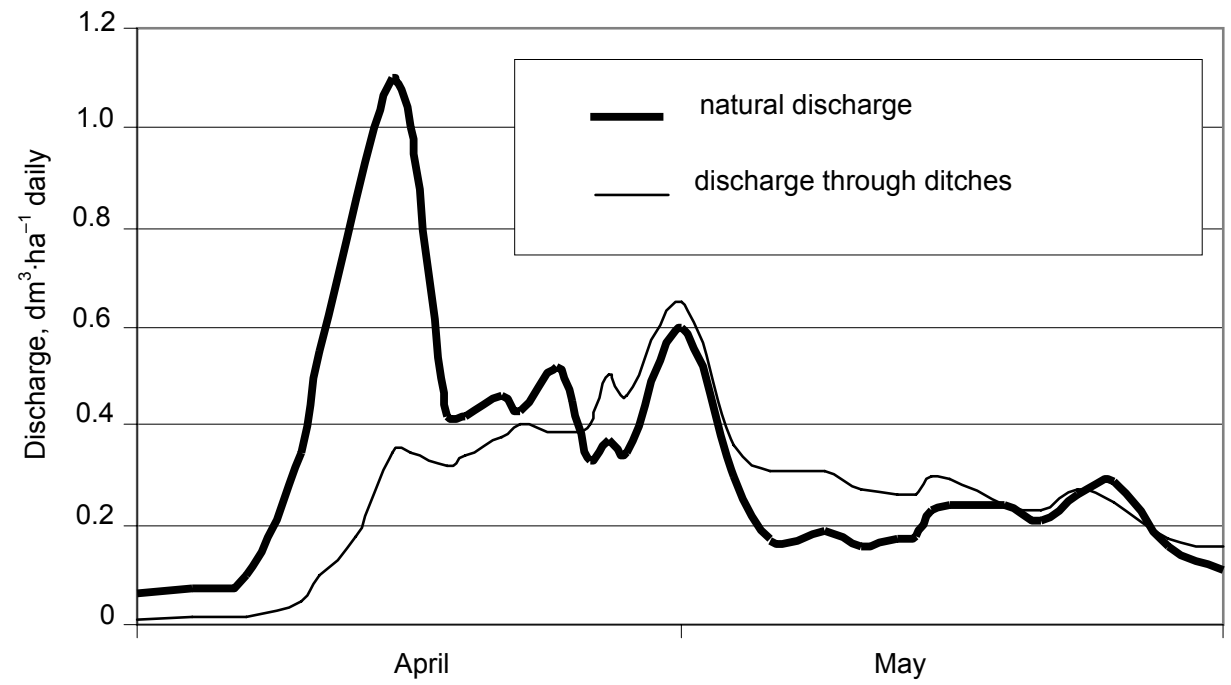

Fig. 7. The regime of water discharge through drainage ditches in 2004 from forests with hydro-morph mineral soils compared to the discharge in a natural outflow - the Veseta River 
nitrogen sinks accumulating the elevated atmospheric deposits in soil or biomass (Atmosferic..., 1992; DISE and WRIGHT, 1995; GUNDERSEN, 1995;). In other studies nitrogen inflow by precipitation to the forest ecosystem varied between 1.0 and $72.0 \mathrm{~kg} \cdot \mathrm{ha}^{-1} \cdot \mathrm{year}^{-1}$ and outflow - between 1.3 and $39.0 \mathrm{~kg} \cdot \mathrm{ha}^{-1} \cdot \mathrm{year}^{-1}$ (DAMBRINE and RANGER, 2000; MATZNER, 1988; MElillo, 1981; MoHR, 1994; NÖMMIK, 1983; ROTHE, 1997). However, some authors (EICHHORN et al., 2001) forecast that nitrogen in forests can reach the limit in the future when an intensive leaching from soil will takes place. The loss of nitrogen and other elements (except phosphorus) from forested catchment was noted by STEVENS et al. (1989). The critical load of nitrogen to coniferous forests was estimated at $10-20 \mathrm{~kg} \cdot \mathrm{ha}^{-1} \cdot \mathrm{year}^{-1}$ (BOBBINK and ROELOFS, 1995), which already can cause the increased outflow of nitrates.

The input of mineral nitrogen $\left(\mathrm{N}-\mathrm{NH}_{4}\right.$ and $\left.\mathrm{N}-\mathrm{NO}_{3}\right)$ in throughfall to forest stands at Vesetnieki amounts on average $14.3 \mathrm{~kg} \cdot \mathrm{ha}^{-1} \cdot \mathrm{year}^{-1}$, whereas the average outflow rates in the post-drainage period are 5.45 and $3.71 \mathrm{~kg} \cdot \mathrm{ha}^{-1} \cdot \mathrm{year}^{-1}$ for the drained peat soils and drained hydromorphic mineral soils, respectively. The present ecosystem nitrogen status at Vesetnieki can be characterized as nitrogen unsaturated for catchments with drained hydromorphic mineral soils, and saturated to a low extent for catchments with drained peat soils. This could be explained by the enhanced foliar uptake of nitrogen or its retention in the interception water found at Vesetnieki and in other studies (BRUMME et al., 1992; LINDBERG et al., 1986;

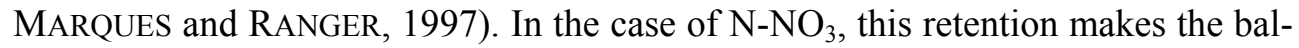
ance of this ion negative: the outflow via ditch runoff exceeds the inflow by precipitation by about $0.17 \mathrm{~kg} \cdot \mathrm{ha}^{-1} \cdot \mathrm{year}^{-1}$. However, the estimation of complete inflow rates of the elements in forest is very difficult because of the variability of deposition paths (IBROM, 1993; LINDBERG et al., 1986; LOVETT, 1994). The same concerns also the paths of element output.

Most likely the negative balance of $\mathrm{Ca}^{2+}$ and $\mathrm{Mg}^{2+}$ ions is due to the soil groundwater and ditch runoff, supplemented by the confined aquifer water from the upper Devonian dolomite layers (ZALITIS and INDRIKSONS, 2003). The outflow of $\mathrm{Ca}^{2+}, \mathrm{Mg}^{2+}$ and $\mathrm{N}-\mathrm{NO}_{3}$ is significantly higher from forests on a deep peat layer than from those on hydromorphic mineral soils (Tab. 2).

On an annual basis, the input of N-NH higher in an open place, while the input of $\mathrm{K}^{+}, \mathrm{Ca}^{2+}$ and $\mathrm{Mg}^{2+}$ is higher under forest canopy (Tab. 2). The forest canopies absorb ammonium ions more intensively than nitrates (LOVETT, 1992; PIIRAINEN et al., 1998; POTTER et al., 1991; STACHURSKI and ZIMKA, 2000), which is shown also in our study. CARLETON and KAVANAGH (1990) observed that the nitrogen foliar uptake increases with the stand age. The throughfall enrichment of potassium, calcium and magnesium was also found in other studies (BREDEMEIER, 1988; RASPE, 1997; ULRICH, 1983).

The balance of nutrients over a year or a longer period is smoothed, i.e. the inflow does not exceed the outflow. Such an inflow/outflow ratio is a significant precondition for ecosystem protection. 
The results of nutrient balance are given in Table 2 .

Table 2. Nutrient balance in water confluence basins in Vesetnieki Station of Permanent Ecological Research $\left(\mathrm{kg} \cdot \mathrm{ha}^{-1} \cdot \mathrm{year}^{-1}\right)$

\begin{tabular}{|c|c|c|c|c|c|c|c|}
\hline \multirow[b]{3}{*}{ Element } & \multicolumn{4}{|c|}{$\begin{array}{l}\text { Time period between } 1997 \text { and } 2001 \text {, } \\
\text { annual mean }\end{array}$} & \multicolumn{3}{|c|}{$\begin{array}{c}\text { Post-drainage period (between } 1968 \\
\text { and 2001, annual mean) }\end{array}$} \\
\hline & \multicolumn{2}{|c|}{$\begin{array}{l}\text { inflow by } \\
\text { precipitation }\end{array}$} & \multicolumn{2}{|c|}{$\begin{array}{l}\text { outflow by } \\
\text { ditch runoff }\end{array}$} & \multirow[b]{2}{*}{$\begin{array}{l}\text { inflow by } \\
\text { precipita- } \\
\text { tion in an } \\
\text { open area }\end{array}$} & \multicolumn{2}{|c|}{$\begin{array}{l}\text { outflow by } \\
\text { ditch runoff }\end{array}$} \\
\hline & $\begin{array}{l}\text { in an } \\
\text { open } \\
\text { place }\end{array}$ & $\begin{array}{c}\text { via } \\
\text { through } \\
\text { fall }\end{array}$ & $\begin{array}{c}\text { drained } \\
\text { peat } \\
\text { soils }\end{array}$ & $\begin{array}{l}\text { drained } \\
\text { hydro- } \\
\text { morph } \\
\text { mineral } \\
\text { soils }\end{array}$ & & $\begin{array}{l}\text { drained } \\
\text { peat soils }\end{array}$ & $\begin{array}{c}\text { drained } \\
\text { hydro- } \\
\text { morph } \\
\text { mineral } \\
\text { soils }\end{array}$ \\
\hline $\mathrm{N}-\mathrm{NH}_{4}$ & 14.80 & 13.90 & 4.88 & 3.50 & 15.20 & 5.60 & 3.80 \\
\hline $\mathrm{N}-\mathrm{NO}_{3}$ & 0.90 & 0.40 & 0.57 & 0.21 & 0.92 & 0.67 & 0.26 \\
\hline $\mathrm{P}-\mathrm{PO}_{4}$ & 1.39 & 0.80 & 0.15 & 0.13 & 1.44 & 0.18 & 0.14 \\
\hline $\mathrm{K}^{+}$ & 11.90 & 16.20 & 4.26 & 2.71 & 12.20 & 4.77 & 3.55 \\
\hline $\mathrm{Ca}^{2+}$ & 37.80 & 39.60 & 170.90 & 104.60 & 38.80 & 193.90 & 119.30 \\
\hline $\mathrm{Mg}^{2+}$ & 15.40 & 16.20 & 55.00 & 29.70 & 15.80 & 61.90 & 35.00 \\
\hline
\end{tabular}

\section{CONCLUSIONS}

The difference between precipitation and evaporation is not the main precondition of paludification of territories in Latvia. The distribution of waterlogged forests is connected with the confined aquifer water discharge areas. $86 \%$ of forests on peat soils and $60 \%$ of forests on hydro-morph mineral soils are located in places where the piezometric level of confined aquifer water reaches and exceeds the soil surface.

The forest hydro-technical drainage enhances the piezometric level of confined aquifer water which means water delivery to rivers in dry summers and the enrichment of mineral nutrients in soil and soil groundwater so ensuring continuous increase of forest productivity.

Productivity of forest does not depend on the thickness of peat layer or on simple decrease of the soil groundwater level but on the difference between the water level in confined aquifer and soil groundwater level $(\Delta h)$. At $\Delta h$ value higher than $0.5 \mathrm{~m}$, peat soils are better supplied with calcium and magnesium than the hydro-morph mineral soils.

The input of $\mathrm{N}-\mathrm{NH}_{4}, \mathrm{~N}-\mathrm{NO}_{3}, \mathrm{P}-\mathrm{PO}_{4}$ and $\mathrm{K}^{+}$to the forest ecosystem with precipitation exceeds the outflow of the same elements in ditch runoff. This suggests that these elements are accumulated in the forest ecosystem. In contrast, the outflow of $\mathrm{Ca}^{2+}$ and $\mathrm{Mg}^{2+}$ in ditch runoff is several times higher than the inflow of the 
respective elements with precipitation, which is caused by the confined aquifer water discharge in this area.

$\mathrm{N}-\mathrm{NH}_{4}, \mathrm{~N}-\mathrm{NO}_{3}$ and $\mathrm{P}-\mathrm{PO}_{4}$ are retained by forest canopy and $\mathrm{K}^{+}, \mathrm{Ca}^{2+}$ and $\mathrm{Mg}^{2+}$ are enriched in throughfall which is connected with the nutrient foliar uptake and leaching, respectively. In case of $\mathrm{N}^{-N}{ }_{3}$, the retention causes changes in the inflow-outflow ratio.

The maximum water discharge in ditches from drained forests is lower than discharge from natural outflows and occurs some weeks later. In forests with peat soils water is discharged through ditches all year round while in forests with hydromorph mineral soils the discharge interrupts in dry summers.

Our long-term measurements undeniably evidence the fact that hydrotechnical drainage of forests does not deteriorate water regime of the natural outflows.

\section{REFERENCES}

1. ANONYMOUS, 1968. Spravočnik po klimatu SSSR (USSR climate manual). Latvijskaja SSR. Č. 4. Vlažnost' vozducha, atmosfernye osadki i snežnyj pokrov. Vipusk 5. Leningrad, Gidrometeorol. izd.: 210.

2. Atmospheric deposition and forest nutrient cycling, 1992. Eds. D.W. Johnson, S.E. Lindberg. Ecol. St. 91. New York, Springer: 707.

3. BobBinK R., Roelofs J.G.M., 1995. Nitrogen critical loads for natural and semi-natural ecosystems: the empirical approach. Water Air Soil Pollut., 85: 2413-2418.

4. BREDEMEIER M., 1988. Forest canopy transformation of atmospheric deposition. Water Air Soil Pollut., 40: 121-138.

5. BRumme R., LeimcKe U., MATZNeR E., 1992. Interception and uptake of $\mathrm{NH}_{4}$ and $\mathrm{NO}_{3}$ from wet deposition by above-ground parts of young beech (Fagus silvatica L.) trees. Plant Soil, 142: 273-279 .

6. Carleton T.J., Kavanagh T., 1990. Influence of forest age and spatial location on throughfall chemistry beneath black spruce. Can. J. Forest Res., 20: 1917-1925.

7. Dambrine E., RAnger J., 2000. Long term nutrient budgets in forests: Lessons from chronosequence studies. In: Forests and society: The role of research. Eds. N. Abdul Rahim, H.F. Lim, M.Y. Aziah, A.R. Mohd Farid. 21st IUFRO World Congr., 7-12 August 2000, Kuala Lumpur, Malaysia. Sub-plenary sessions, 1: 687-694.

8. DisE N.B., WRIGHT R.F., 1995. Nitrogen leaching from European forests in relation to nitrogen deposition. Forest Ecol. Manag., 71: 153-161.

9. EichHorn J., Haussmann T., PAar U., Reinds G.J., VRies W., 2001. Assessment of impacts of nitrogen deposition of beech forest: Results from the Pan-European intensive monitoring programme. Sci. World, 1.1 (S2): 423-432.

10. GUNDERSEN P., 1995. Nitrogen deposition and leaching in European forests - Preliminary results from a data compilation. Water Air Soil Pollut., 85: 1179-1184.

11. IBRom A., 1993. Die Deposition und die Pflanzenauswashung (Leaching) von Pflanzennährstoffen in einem Fichtenbestand im Solling. (Nutrients deposition and leaching in a spruce stand in Solling). Berichte Forschungszentr. Waldökosyst., A Bd., 105: 165.

12. LindBerg S.E., LOVetT G.M., Richter D.D., Johnson D.W., 1986. Atmospheric deposition and canopy interactions of major ions in a forest. Sci., 231: 141-145. 
13. LovetT G.M., 1992. Atmospheric deposition and canopy interactions of nitrogen. In: Atmospheric deposition and forest nutrient cycling. Eds. D.W. Johnson, S.E. Lindberg. Ecol. St., 91. New York, Springer: $152-166$.

14. LOvetT G.M., 1994. Atmospheric deposition of nutrients and pollutants in North America: An ecological perspective. Ecol. Appl., 4(4): 629-650.

15. MARQUES R., RANGER J., 1997. Nutrient dynamics in a chronosequence of Douglas fir (Pseudotsuga menziesii (Mirb.) Franco) stands on the Beaujolais Mounts (France). 1 Qualitative approach. Forest Ecol. Manag., 91: 255-277.

16. MATZNER E., 1988. Der Stoffeumsatz zweier Waldökosysteme im Solling (The nutrient cycle in two forest ecosystems in Solling). Berichte Forschungszentr. Waldökosyst. / Waldsterben, A, Bd., 40: 217.

17. Melillo J.M., 1981. Nitrogen cycling in deciduous forests. In: Terrestrial Nitrogen Cycles Process. Ecosyst. Strategies Manag. Impacts. Proc. Int. Workshop, Österfärnebo, 16-22 Sept., 1979, Stockholm: 427-442.

18. MoHR H., 1994. Stickstoffeintrag als Ursache neuartiger Waldschäden (Input of nitrogen as cause for new forest decline). Spektrum der Wissenschaft, Januar 1994: 48-53.

19. NÖMMIK H., 1983. Kväve - och fosforbudget for svenskt skogsbruk (Nitrogen and phosphorus balance in Swedish forestry). Kungl. Skogs - och Lantbruksakademien tidskrift, 5(122): 303-309.

20. OSTWALD E., 1878. Über den Einfluss der Entwässerungen versumpfter Orte auf den Baumwuchs. Baltische Woch. - Schr., 13: 16-22.

21. PASTORS A., 1972. Vodnyj balans Latvijskoj SSR (The water balance of Latvian SSR). Upravlenie gidrometslužbi Latvijskoj SSR. Riga: 49.

22. PiIRAinen S., Finer L., Starr M., 1998. Canopy and soil retention of nitrogen deposition in a mixed boreal forest in Eastern Finland. Water Air Soil Pollut., 105: 165-174.

23. Potter C.S., Ragsdale H.L., Swank W.T., 1991. Atmospheric deposition and foliar leaching in a regenerating Southern Appalachian forest canopy. J. Ecol., 79: 97-115.

24. RASPE S., 2001. Konzepte für eine integrierende Standardauswertung der Messergebnisse von den Bayerischen Waldklimastationen (Conceptions for an integrated standard-evaluation of the data from Bavaria Forest climate Stations). Forstliche Forschungsberichte München, 184: 180.

25. Rотне A., 1997. Einfluss des Baumartenanteils auf Durchwurzelung, Wasserhaushalt, Stoffhaushalt und Zuwachsleistung eines Fichten-Buchen-Mischbestandes am Standort Höglwald (Influence of tree species composition on rooting patterns, hydrology, elemental turnover, and growth in a mixed spruce - beech stand in Southern Germany (Höglwald)). Forstliche Forschungsberichte München, $163,204$.

26. StaChURSKi A., Zimka J.R., 2000. Atmospheric input of elements to forest ecosystems: A method of estimation using artificial foliage placed above rain collectors. Env. Pollut., 110: 345-356.

27. Stevens P.A., Hornung M., Huges S., 1989. Solute concentrations, fluxes and major nutrient cycles in a mature Sitka-spruce plantation in Beddgelert Forest, North Wales. Forest Ecol. Manag., 27: $1-20$.

28. ULRICH B., 1983. Interaction of forest canopies with atmospheric constituents: $\mathrm{SO}_{2}$, alkali and earth alkali cations and chloride. In: Effects of accumulation of air pollutants in forest ecosystems. Eds B. Ulrich, J. Pankrath. Dordrecht, D. Reidel: 33-45.

29. ZALITIS P., 1983. Osnovy rational'nogo lesoosušenija v Latvijskoj SSR (Basics of rational forest drainage in Latvian SSR). Riga, Zinatne: 230.

30. ZALITIS P., INDRIKSONS A., 2003. Pazemes spiedes udenu ietekme uz parpurvoto un melioreto mezu razibu Latvija (The impact of underground pressure water on the productivity of bogged and drained forests in Latvia). Latvijas Lauksaimniecības universitātes Raksti, 9 (304): 38-45. 


\section{STRESZCZENIE}

\section{Hydrologiczne właściwości podmokłych i drenowanych lasów Łotwy}

Słowa kluczowe: odpływ wody, paludyfikacja lasu, pierwiastki biogenne, podmokłe lasy

Niemal połowa (47\%) obszarów leśnych Łotwy (3611 tys. ha) jest zdegradowana bądź częściowo zmieniona przez hydrotechniczne odwadnianie. Degradację powoduje słabe napowietrzenie zalanych wodą gleb. Rozmieszczenie podmokłych lasów Łotwy nie jest ani równomierne, ani losowe. Porównanie występowania podmokłych lasów z wielkością opadów atmosferycznych wskazuje, że lasy te są zlokalizowane głównie na obszarach o najmniejszej ilości opadów. To hydrologiczne zjawisko jest związane $\mathrm{z}$ odpływem wody kanałami odwadniającymi. Nawet podczas suchego lata w latach 1963, 1964, 1975, 1976 i 2002 w lasach z gruba warstwą torfowych gleb woda płynęła ciągle kanałami o głębokości $1 \mathrm{~m}$, a odpływ przekraczał wielkość opadów. Na podstawie danych ze 182 poletek w drenowanych lasach o miąższości torfu 4,2 m ustalono, że lasy iglaste są najbardziej produktywne na obszarach o największej gęstości warstwy torfowej. Jednym z możliwych wyjaśnień tego zjawiska jest fakt, że najintensywniejsza paludyfikacja i tworzenie warstw torfu o największej gęstości występuje na obszarach o intensywnym odpływie wody $\mathrm{z}$ warstw wodonośnych o napiętym zwierciadle wody. Ten odpływ zapewnia glebie leśnej niezbędne substancje mineralne niezależnie od miąższości torfu. Produktywność lasu może wzrosnąć kilkakrotnie dzięki wzmożonemu przepływowi wody $\mathrm{w}$ glebie $\mathrm{i}$ aeracji zwiększonej przez hydrotechniczne odwadnianie. Reżim przepływu wody w rzekach powiązanych z drenowanym obszarem także ulega znaczącym zmianom, łagodząc skutki skrajnie wysokich lub niskich stanów wody.

Reviewers:

Prof. Andrzej Ciepielowski

Prof. Antoni Miler 